http://dx.doi.org/10.12775/szhf.2019.006

\author{
JERZY KOPANIA \\ Akademia Teatralna w Warszawie - Filia w Biąymstoku, Polska \\ ORCID: 0000-0002-5999-1713 \\ E-MAIL: JERZYKOPANIA@O2.PL
}

\title{
René Descartes jako prekursor ideologii transhumanizmu
}

Rozwój wiedzy rodzi nadzieję na coraz skuteczniejsze korzystanie z dóbr przyrody, coraz lepsze zabezpieczenie się przed tym wszystkim, co z jej strony człowiekowi zagraża, przede wszystkim zaś na coraz lepsze, zdrowsze i dłuższe życie. Czasem, w którym te nadzieje zostały rozbudzone w stopniu dotychczas niespotykanym, było XVII stulecie, a myślicielem, który w sposób szczególny do tego się przyczynił, jak też sam głęboko wierzył, iż nauka zmieni zasadniczo życie człowieka, był René Descartes. Tą samą wiarą napełnieni są współcześni transhumaniści, a choć nie przejęli jej bezpośrednio od ojca nowożytnego racjonalizmu, to porównanie wiary kartezjańskiej z wiarą transhumanistyczną jest wymowne i pozwala lepiej zrozumieć, w jakim kierunku zmierzamy. 


\section{Ulepszyć świat i człowieka}

Prawdą jest, że „nowa filozofia” Descartes’a przyczyniła się do rozwoju nauk przyrodniczych, a on sam był tego świadom i wiązał z rozwojem wiedzy wielkie nadzieje. W Rozprawie o metodzie, manifeście programowym swej filozofii, pisał (w części szóstej), że w miejsce filozofii spekulatywnej należy rozwijać filozofię praktyczną, czyli wiedzę o prawach rządzących wszechświatem, która umożliwiać będzie uzyskiwanie coraz większych korzyści praktycznych i pozwoli ludziom „stać się jak gdyby panami i posiadaczami

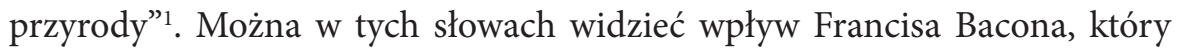
z irytacją oskarżał filozofię, iż utrwala w ludziach niewiarę we własne siły, ponieważ przekonuje ich, że nie powinni od siebie samych „oczekiwać niczego wielkiego, niczego, co by dawało panowanie i przewagę nad przyrodą”2, on zaś nawoływał, dając samemu dobry przykład, aby rozwijać rzetelną wiedzę o przyrodzie. Można też uznać je za powtórzenie słów z Księgi Rodzaju, słów skierowanych przez Boga do pierwszych stworzonych przez siebie ludzi: „Bądźcie płodni i rozmnażajcie się, abyście zaludnili ziemię i uczynili ją sobie poddaną; abyście panowali nad rybami morskimi, nad ptactwem powietrznym i nad wszystkimi zwierzętami pełzającymi po ziemi”" . Człowiek chce podporządkować sobie przyrodę, czerpać z jej bogactwa i chronić się przed zagrożeniami z jej strony, ponieważ wie, że od tego zależy jego przetrwanie i jakość jego życia. Nie dziwi zatem, że wszelkie działania owo panowanie wzmacniające człowiek uznaje za aprobowane przez samego Boga.

Descartes nie miał najmniejszych wątpliwości, że stałe dążenie do rozwoju wiedzy jest moralną powinnością wszystkich, których zdolności intelektualne do tego uzdatniają. Kolejne zdobycze nauki ułatwiają i polepszają bytowanie człowieka, a przecież każdy, kto może pomóc drugiemu człowiekowi, uczynić to powinien. Przytoczmy słowa z Rozprawy o metodzie, w których Descartes wyjaśnia, dlaczego tak ważne jest rozwijanie filozofii praktycznej, czyli stałe poszerzanie i pogłębianie wiedzy naukowej.

\footnotetext{
${ }^{1}$ René Descartes, Rozprawa o metodzie, przeł. Wanda Wojciechowska (Warszawa: PWN, 1970), 72.

${ }^{2}$ Francis Bacon, Novum Organum, przeł. Jan Wikarjak (Warszawa: PWN, 1955), 116.

${ }^{3}$ Rdz 1,28; przekład Biblii Tysiąclecia.
} 
Jest to nie tylko pożądane dla wynalezienia niezliczonego mnóstwa umiejętności, które by pozwoliły na korzystanie bez żadnego trudu z płodów ziemi i wszelkich dogodności, jakie się na niej znajdują, lecz przede wszystkim także dla zachowania zdrowia, które jest niewątpliwie naczelnym dobrem oraz podwaliną wszelkich innych dóbr tego życia; nawet umysł bowiem jest w tak wielkiej zależności od temperamentu i od układu narządów ciała, że jeśli tylko jest możliwe znalezienie jakiegokolwiek środka, który by uczynił ludzi na ogół mądrzejszymi i zręczniejszymi, niż byli dotychczas, mniemam, iż należy go szukać w medycynie. Wprawdzie ta, która obecnie jest w użyciu, zawiera niewiele rzeczy tak znacznej użyteczności; nie mając jednak zamiaru uwłaczać jej wyznawcom, jestem pewien, że nie ma nikogo nawet wśród tych, którzy ją uprawiają, kto by nie przyznał, że wszystko, co w niej jest znane, jest niczym prawie w porównaniu z tym, co pozostało do poznania, a również, że można by się wyzwolić od niezliczonego mnóstwa chorób tak ciała, jak umysłu, a może nawet także od starczej niemocy, gdyby się posiadało dość wiedzy o ich przyczynach oraz o wszystkich lekach, w które zaopatrzyła nas przyroda ${ }^{4}$.

Descartes zdecydował się „poświęcić całe swe życie poszukiwaniom tak potrzebnej wiedzy"5. Pracował twórczo w dziedzinie matematyki, fizyki, optyki, meteorologii, biologii, psychologii. Ale większą rolę odegrał jako filozof niż jako przyrodnik. Jednak wtedy, gdy pisał Rozprawę o metodzie, dziełko mające stanowić filozoficzny i metodologiczny wstęp do trzech traktatów naukowych, był głęboko przekonany, że nauka zmieni świat i człowieka. Równie głęboko wierzył, że to on wniesie wielki wkład w rozwój wiedzy ludzkiej.

W zacytowanym fragmencie Descartes wymienia cztery sfery rzeczywistości przyrodniczej i ludzkiej, które dzięki rozwojowi wiedzy i technologii można będzie ulepszać. Są to: przyroda ożywiona i nieożywiona, cielesność człowieka, psychika człowieka i ludzka moralność. W tym przekonaniu kryje się marzenie o ulepszającym zmienianiu wszystkiego, co istnieje w przestrzeni ludzkiego doświadczenia, czyli całej rzeczywistości - zarówno materialnej, jak i duchowej. Descartes nie stawia przy tym pytania, czy istnieje kres, jakaś nieprzekraczalna granica tego poprawiania rzeczywistości. To pytanie postawili 300 lat później transhumaniści - wyznawcy ideologii, której podstawę stanowi niezłomna wiara, iż rozwój nauki i technologii doprowadzi

\footnotetext{
${ }^{4}$ Descartes, Rozprawa o metodzie, 72-73.

5 Tamże, 73.
} 
do tak dalece idących przemian świata i człowieka, że będzie to już inny świat i inny człowiek ${ }^{6}$.

W ideologii transhumanizmu najpełniej wyraża się pragnienie ulepszającej przemiany całej rzeczywistości. Transhumaniści poszukują swoich prekursorów już w starożytności ${ }^{7}$, odwołują się do myśli oświeceniowej ${ }^{8}$, ale Descartes’a nie wymieniają wśród swych poprzedników. Bardzo eksplikatywne rozumienie ideologii transhumanizmu podał brytyjski filozof i futurolog Max More w opublikowanym w 1990 roku eseju Transhumanism: Toward a Futurist Philosophy, w którym wyłożył podstawowe założenia i cele doktryny9. Określił w nim transhumanizm jako dążenie do osiągnięcia przez człowieka stanu "postludzkiego"10, który będzie się charakteryzował wyeliminowaniem chorób i ułomności, zatrzymaniem procesu starzenia się, wydłużaniem życia w nieskończoność i zwiększeniem intelektualnych oraz psychicznych możliwości w stopniu tak dalece przekraczającym to wszystko, czym człowiek dysponuje obecnie, że te nowe istoty nie będą już ludźmi w dzisiejszym rozumieniu tego słowa.

Dążenie do tego celu oparte jest na założeniu, że ewolucja człowieka doszła do kresu i teraz nadchodzi czas, aby człowiek ujął we własne ręce ewolucję swego gatunku. Max More mówi o tym wprost w krótkim tekście o charakterystycznym tytule: List do Matki Natury.

Matko Naturo, jesteśmy naprawdę wdzięczni za to, jakimi nas stworzyłaś. Niewątpliwie dokonałaś wszystkiego, co było w twojej mocy. Jednak, z całym szacunkiem, musimy zauważyć, że pod wieloma względami efekty pozostawiają wiele do życzenia. Uczyniłaś nas wrażliwymi na choroby i uszkodzenia. Poddałaś nas starzeniu i śmierci - właśnie wtedy, gdy zaczynamy osiągać mądrość.

\footnotetext{
${ }^{6}$ Ideologię transhumanistyczną rozumiemy tutaj szeroko, zaliczając do niej wszelkie postawy i działania motywowane chęcią ulepszania (enhancement) człowieka. Ideologię zaś pojmujemy jako światopogląd z wpisanym weń programem realizacji określonych celów.

${ }^{7}$ Nick Bostrom, „A History of Transhumanist Thought”, Journal of Evolution and Technology 14, 1 (2005): 1-25.

${ }^{8}$ James Hughes, „Contradictions from the Enlightenment Roots of Transhumanism”, Journal of Medicine and Philosophy 35, 6 (2010), 622-640.

${ }_{9}^{9}$ Max More, Transhumanism: Toward a Futurist Philosophy, dostęp: 27.07.2018, http://web. archive.org/web/20130806172107/http://www.maxmore.com:80/transhum.htm.

${ }^{10}$ „Transhumanism is a class of philosophies that seek to guide us towards a posthuman condition"; tamże.
} 
Raczej skąpo obdarzyłaś nas świadomością własnych cielesnych, poznawczych i emocjonalnych procesów. Zawiodłaś nas, dając innym zwierzętom ostrzejsze zmysły. Uczyniłaś nas zdolnymi do przetrwania tylko w wąsko określonych warunkach środowiskowych. Dałaś nam ograniczoną pamięć, słabą kontrolę nad impulsami, a także plemienne, ksenofobiczne popędy. No i zapomniałaś dołączyć instrukcji obsługi. To, jakimi nas uczyniłaś, jest cudowne, ale i głęboko wadliwe. A przy tym wydaje się, że straciłaś zainteresowanie naszą dalszą ewolucją jakieś 100 tysięcy lat temu. A może po prostu czekasz, aż my sami zrobimy następny krok. Tak czy owak doszliśmy do kresu naszego dzieciństwa. Zdecydowaliśmy, że nadszedł czas, byśmy wnieśli pewne poprawki w konstrukcji człowieka ${ }^{11}$.

Transhumanizm jest więc wyrazem przekonania, że dalsza ewolucja gatunku ludzkiego dokonywać się będzie już nie siłami natury, lecz człowieka. Znaczy to jednak, że człowiek musi tak zmienić samą naturę (przyrodę), aby mógł wyznaczać kierunki jej rozwoju, dzięki czemu możliwe będzie ulepszanie jego cielesności, psychiki i moralności ${ }^{12}$. Jest to ta sama wiara w potęgę wiedzy i ta sama nadzieja nadejścia świata doskonalszego, którą żywił Descartes - tyle że transhumaniści zdają się mieć i tę wiarę, i tę nadzieję w stopniu co najmniej o tyle większym, o ile większy jest stopień współczesnej wiedzy w porównaniu $\mathrm{z}$ tą sprzed 300 lat.

Max More, kierując swe uwagi do Matki Natury, czyni ironiczną sugestię: „Być może mogłabyś przekazać je Ojcu, bo my jakoś nigdy go nie widzieliśmy w pobliżu"13. W cywilizacji zachodniej zanika wiara w Boga i w nadprzyrodzone życie wieczne, a na jej miejsce wchodzi wiara w boską potęgę ludzkiego umysłu. Transhumaniści jakby uwierzyli w biblijną obietnicę szatana złożoną pierwszym rodzicom w raju: „Na pewno nie umrzecie! Ale wie Bóg, że gdy spożyjecie owoc z tego drzewa, otworzą się wam oczy i tak jak Bóg będziecie znali dobro i zło"14. Istota ideologii transhumanizmu wyraża

${ }^{11}$ Max More, „List do Matki Natury”, przeł. M. Sieńko, dostęp: 27.07.2018. http://www.racjonalista.pl/kk.php/s,4003/q,List.do.Matki.Natury. Gdy More pisze o dojściu do kresu dzieciństwa, przypominają się słowa Kanta o oświeceniu jako wyjściu człowieka z niepełnoletności.

12 „Człowiek na dzień dzisiejszy nie musi być zwieńczeniem ewolucji”; Nick Bostrom, „Wartości humanistyczne”, przeł. Elżbieta Binswanger-Stefańska, Sławomir Szostak, dostęp: 27.09.2017. www.racjonalista.pl/kk.php/s,6014.

13 Tamże.

${ }^{14} \operatorname{Rdz} 3,4-5$. 
się w przekonaniu, że człowiek nie tylko może, ale i musi doskonalić zarówno przyrodę, jak i swoją własną naturę we wszystkich trzech aspektach: fizycznym, psychicznym i moralnym. Można uznać, że to, co u Descartes’a było wiarą i nadzieją, u transhumanistów stało się utopijnym projektem. A takie projekty to mają do siebie, że zawsze znajdą się chętni, aby je wprowadzać w życie, nie zważając nie tylko na trudności i koszty, ale nawet na towarzyszące temu tragedie ${ }^{15}$. Porównawcze zestawienie marzeń i nadziei Descartes’a z niewzruszoną wiarą transhumanistów pozwala przewidywać, w jakim kierunku zmierza cywilizacja zachodnia.

\section{Droga do celu}

\subsection{Ulepszanie przyrody}

Descartes był pewien, że dzięki nauce ludzie staną się władcami i posiadaczami przyrody, czyli - ujmując to inaczej - przyroda stanie się własnością ludzi. Człowiek po to ma swoją własność, aby z niej korzystać; w wypadku przyrody jest to tym bardziej oczywiste, że korzystanie z przyrody jest warunkiem koniecznym ludzkiej egzystencji. Stosunek Descartes'a do przyrody był konsekwencją jego dualistycznej metafizyki, wedle której rzeczywistość w jej ogólnym aspekcie bytowym tworzy Bóg, czyli substancja czysto duchowa, i świat przyrody, czyli substancja czysto materialna, a na poziomie bytu ludzkiego dusza, czyli substancja myśląca, i ciało, czyli substancja materialna. Ludzka dusza nie jest jakąś emanacją boskiego ducha, lecz jest przez Boga stwarzana w każdym akcie narodzin, a ciała ludzkiego nie wyłania z siebie materialna przyroda, lecz jest ono stwarzane przez Boga jako materialne. Bóg stworzył świat i podtrzymuje go w istnieniu, ale raz nadawszy mu prawa, wedle których działa, od tego momentu nie ingeruje już w bieg zjawisk przyrodniczych. Analogicznie Bóg, stwarzając ludzką duszę, obdarza ją wolnością

15 „Utopijni inżynierowie stają się wszechpotężni i wszechwiedzący, stają się bogami. I nie będziesz miał innych bogów przed nimi”; Karl R. Popper, „Utopia a przemoc”, w: tenże, Droga do wiedzy. Domysty i refutacje, przeł. Stefan Amsterdamski (Warszawa: Wydawnictwo Naukowe PWN, 1999), 598. 
(wolną wolą), a stwarzając ludzkie ciało, wyposaża je we właściwe mu prawa rozwoju i działania, których dusza ludzka nie może zmienić. $Z$ woli Boga więc te dwie substancje są odrębne w swym istnieniu i autonomiczne w swym działaniu.

Podstawowe wskazanie, do którego zdają się prowadzić przedstawione rozstrzygnięcia, głosi, że stosunek człowieka do własnego ciała powinien być podobny do stosunku Boga wobec przyrody. Descartes faktycznie taką postawę przyjmuje i w konsekwencji uznaje, że z jednej strony człowiek powinien dbać o własne ciało, $\mathrm{z}$ drugiej zaś panować nad nim w możliwie największym stopniu. Zauważmy, iż skoro człowiek został stworzony na obraz i podobieństwo Boga, Bóg zaś dał człowiekowi przyrodę we władanie, to człowiek powinien wobec przyrody stosować te same zasady postępowania co do własnego ciała. Powinien zatem troszczyć się o przyrodę, podobnie jak troszczy się o własne ciało, pamiętając, że jest od przyrody równie uzależniony w swym istnieniu, jak od własnego ciała, a zarazem korzystać z dóbr przyrody, tak jak korzysta z możliwości, które mu daje jego ciało. A ponieważ troska o ciało ma charakter troski ulepszającej - staramy się w miarę możliwości wzmacniać i ulepszać nasze ciało - to i wobec przyrody usprawiedliwione są, a nawet wskazane, wszelkie działania zmierzające do jej ulepszania ${ }^{16}$. Rozwój wiedzy i technologii ma prowadzić do coraz głębszego poznawania praw rządzących przyrodą i dostarczać coraz bardziej skutecznych narzędzi służących do korzystania $\mathrm{z}$ jej dóbr ${ }^{17}$. Naukowa penetracja wszechświata jest możliwa, ponieważ jest on jednorodnie materialny, rządzi się stałymi prawami, a działa

${ }^{16}$ Szerzej na temat Descartes'a rozumienia postawy człowieka wobec przyrody zob. Jerzy Kopania, „Ekologia kartezjańska - wprowadzenie do problemu”, w: tenże, Szkice kartezjańskie (Kraków: Aureus, 2009), 181-198.

${ }^{17}$ Podzielamy dawno wyrażoną opinię Émile’a Boutroux, że myślenie filozoficzne Descartes’a bardziej jest nastawione na poznawanie człowieka niż na badanie świata - wiedzę należy rozwijać nie dla niej samej, lecz ku pożytkowi rodzaju ludzkiego. „D’une manière générale, ce n'est pas la science qui est le centre de la philosophie cartésienne, c'est l'homme, et, dans l'homme, la raison. Déjà quand il cultive les sciences de la nature, ce n'est pas la science même que le philosophe a en vue, c'est la formation du jugement par la science. Le jugement est la capacité de discerner en toutes choses, sans hésitation ni incertitude, le vrai d’avec le faux. Or pour y parvenir il faut que nous développions en nous une sorte de sens de la vérité. Les mathématiques, et en particulier l'algèbre, y contribuent merveilleusement”; Émile Boutroux, „Du rapport de la morale a la science dans la philosophie de Descartes”, Revue de Métaphysique et de Morale 4, 4 (1896), 508. 
na zasadzie mechanistycznej - kosmos jest wielką maszynerią, a ciało zwierzęce, także ciało człowieka, to po prostu maszyna organiczna ${ }^{18}$.

Wyznawcy ideologii transhumanizmu faktycznie przyjęli tę samą postawę wobec przyrody. Ponieważ jednak nigdy nie udało im się dostrzec Ojca - jak to ujął Max More - więc w świecie bez Boga przyroda może podlegać nie tylko działaniom ulepszającym, ale i udoskonalającym ją. Descartes nie mógł uznać, że człowiek zdolny jest udoskonalić przyrodę, znaczyłoby to bowiem, że człowiek jest w stanie poprawić boskie dzieło stworzenia. Transhumaniści nie czuli się w najmniejszym stopniu skrępowani w tym względzie - uznali, że ewolucja doszła do kresu swych możliwości, a zatem dzieło ulepszania natury musi ująć w swe ręce człowiek. Tak jak Descartes, również oni uznają jedność i jednorodność materialną przyrody, choć różnią się oczywiście co do kwestii istnienia sfery nadnaturalnej. Ale właśnie dlatego ich rozumienie jednorodności przyrody narzuca im rozumienie człowieka jako bytu jednorodnie materialnego, którego cielesność i psychika stanowią jedność. Zatem odpowiednio modyfikując elementarne składniki cielesności i mechanizmy ich współdziałania, będziemy mogli ulepszyć człowieka zarówno w jego aspektach somatycznych, jak i psychicznych, w tym intelektualnych ${ }^{19}$. Ale

${ }^{18}$ Przyrodnik w odróżnieniu od filozofa bada przyrodę nie po to, aby dociekać istoty rzeczy, lecz w celach praktycznych, tzn. aby dzięki zrozumieniu, jak działa mechanizm przyrody, odnosić korzyści praktyczne. Przyrodnik nie spekuluje na temat ukrytych sił działających w rzeczach, lecz badając elementy uchwytne zmysłami, stawia hipotezę, jakie są ukryte mechanizmy ich działania. „Dlatego tak jak wprawni mechanicy, którzy znając zastosowanie jednej maszyny i widząc pewne jej części, łatwo wnioskują, jaka jest konstrukcja innych niewidocznych jej części, tak samo i ja starałem się na podstawie zmysłowo dostrzegalnych skutków i części ciał naturalnych zbadać, jakie są ich przyczyny i jakie są ich niedostrzegalne cząstki”; René Descartes, Zasady filozofii, przeł. Izydora Dąmbska (Warszawa: PWN, 1960), 350.

${ }_{19}$ Tymi elementarnymi składnikami organizmu ludzkiego są geny. Ray Kurzweil, jeden z najbardziej wpływowych głosicieli idei transhumanizmu, widzi proces ulepszania człowieka jako ciąg kolejnych prostych działań na materiale genetycznym. „U podstaw wszystkich cudów życia i cierpień będących efektem choroby leżą procesy przekazywania informacji, zasadniczo programy o zaskakująco zwartym charakterze. Cały genom ludzki jest sekwencyjnym kodem binarnym zawierającym jedynie około 800 milionów bajtów informacji. [...] kiedy za pomocą konwencjonalnych technik kompresji usunie się [...] redundancje, zostanie nam zaledwie 30-100 milionów bajtów, czyli tyle, ile zajmuje przeciętny współczesny program komputerowy. Kod ten obsługiwany jest przez zespół maszyn biochemicznych tłumaczących owe liniowe (jednowymiarowe) sekwencje »liter « DNA na łańcuchy zbudowane z prostych cegiełek zwanych aminokwasami, które następnie, fałdując się, tworzą trójwymiarowe białka, a z tych zbu- 
jednorodność materialna przyrody umożliwi także zastąpienie bardzo nietrwałego organicznego (białkowego) podłoża ludzkiej świadomości podłożem trwalszym, nieorganicznym (np. krzemowym), jak też pozwoli w przyszłości na przenoszenie jej na elektroniczne układy sieciowe, czyli zapewni człowiekowi nieśmiertelnośćc ${ }^{20}$. Nie będzie to jednak przejście do jakiejś odrębnej substancjalnie sfery rzeczywistości, ponieważ jest tylko jedna rzeczywistość materialna, której częścią będzie nowy człowiek ${ }^{21}$.

Transhumaniści faktycznie uznają mechanistyczny charakter tak wszechświata, jak i człowieka. Dlatego mechanistyczne w istocie modyfikowanie człowieka, tworzenie nowego gatunku ludzkiego, musi być zarazem modyfikowaniem wszechświata jako takiego. Nowy człowiek, rozprzestrzeniający swą inteligencję w całym wszechświecie, nada rzeczywistości przyrodniczej nową jakość, ponieważ przestanie być jedynie jej częścią, a utworzy z nią jedność organiczną. Postludzka inteligencja rozprzestrzeniona w kosmosie będzie korzystać z jego możliwości i posługiwać się nim analogicznie do inteligencji ludzkiej, rozprzestrzenionej w ludzkim ciele, która posługuje się nim i korzysta z jego możliwości ${ }^{22}$. Wszechświat stanie się ciałem postczłowieka. Transhumaniści w swych wizjach wyszli daleko poza horyzont myślowy Descartes'a - ale punkt wyjścia był ten sam.

dowane są wszystkie istoty żywe, od bakterii po ludzi”; Ray Kurzweil, Nadchodzi Osobliwość. Kiedy człowiek przekroczy granice biologii, przeł. Eliza Chodkowska i Anna Nowosielska (Warszawa: Kurhaus, 2013), 204.

${ }^{20}$ Wspomniany Kurzweil przewiduje powstanie nowego, niebiologicznego gatunku ludzkiego. „Najważniejsze jest to, że inteligencja, która powstanie, będzie nadal reprezentować ludzką cywilizację, będącą już wtedy cywilizacją ludzko-maszynową. Innymi słowy, przyszłe maszyny będą istotami ludzkimi, chociaż nie będą wytworem biologii. [...] Większa część inteligencji naszej cywilizacji będzie ostatecznie niebiologiczna. Pod koniec tego stulecia będzie ona biliony bilionów razy potężniejsza od inteligencji ludzkiej”; tamże, 42. Kurzweil wyznaje: „Naprawdę wierzę, że my, ludzie, w końcu zaakceptujemy istnienie świadomości podmiotów niebiologicznych”; tamże, 377.

${ }^{21}$ Przywołajmy znów Kurzweila: „Nawet formy niebiologiczne będą pochodzić z biologicznego projektu. Nasza cywilizacja pozostanie w rzeczy samej ludzka, na wiele sposobów będzie bardziej przykładem tego, co uważamy za ludzkie, niż to jest dzisiaj, ale nasze rozumienie tego terminu wykroczy poza jego biologiczne początki”; tamże, 42.

${ }^{22}$ Jeszcze raz zacytujmy Kurzweila: „Ostatecznie cały wszechświat nasyci się naszą inteligencją. Taka będzie jego przyszłość. To my będziemy określać własny los, który raczej nie będzie zdeterminowany przez obecne »bezrozumne«, proste, maszynowe siły, które rządzą mechaniką nieba"; tamże, 41 . 


\subsection{Ulepszanie cielesności}

Descartes odseparował duszę ludzką od ludzkiego ciała, czyli uznał, że ciało wyposażone jest we własną siłę życiową i nie potrzebuje aktów duszy dla swych działań; było to zerwanie z całą dotychczasową, wywodzącą się ze starożytności tradycją przypisującą duszy właściwość ożywiania materii. Towarzyszyło temu odmówienie posiadania duszy (w jakiejkolwiek postaci) zwierzętom, które uznane zostały za byty wyłącznie materialne, za organiczne mechanizmy. Ale istotną i głęboką konsekwencję stanowiło uznanie, że dusza ludzka - czyli człowiek w swej istocie - jest zewnętrzna względem ludzkiego ciała. Wprawdzie jest z ciałem jakoś związana i zachodzą między nimi wzajemne oddziaływania, dzięki czemu to oto ciało staje się cielesnością tego oto człowieka, ale mimo to człowiek pozostaje względem swego ciała w relacji analogicznej do swego odzienia; jest to analogia zasadna co do istoty związku, choć oczywiście nie co do jego mocy, jako że więź duszy z ciałem jest nieporównanie silniejsza niż więź człowieka z jego odzieniem ${ }^{23}$.

Takie rozumienie relacji między duszą a ciałem daje uzasadnienie dla bardzo daleko idącej ingerencji człowieka we własną cielesność. Człowiek może nie tylko ulepszać swoje ciało - i nie będzie to poprawianie dzieła Bożego jako takiego, lecz udoskonalające zwiększanie możliwości tkwiących w samym stworzonym przez Boga ciele. Człowiek staje się uprawniony, a nawet ma moralny obowiązek tak modyfikować swoje ciało, aby służyło mu jak najlepiej, nie podlegało chorobom i trwało w jak najlepszym stanie jak najdłużej. Przed Descartes’em przyjmowano, że dusza ożywia ciało, a więc ciało umiera, gdy dusza je opuszcza. Descartes twierdził przeciwnie: to mechanizm ciała zaczyna w miarę upływu czasu i wskutek chorób czy uszkodzeń działać coraz gorzej, ruch jego części słabnie i staje się coraz mniej skoordynowany, aż wreszcie samoistne funkcje cielesne ustają i wówczas dusza opuszcza martwe ciało $^{24}$. Wynika z tego wniosek, że jak długo uda się nam utrzymywać mechanizm ciała w sprawności, tak długo dusza będzie w nim pozostawać.

\footnotetext{
${ }^{23}$ Szerzej o kartezjańskim rozumieniu cielesności i kartezjańskiej wierze w medycynę zob. Jerzy Kopania, Etyczny wymiar cielesności, (Kraków: Aureus, 2002), 13-46.

${ }^{24} \mathrm{~W}$ traktacie Le passions de lâme („O uczuciach duszy”) Descartes wyjaśniał, że dusza opuszcza ciało, gdy „psują się narządy, które służą do poruszania ciała”, i że „śmierć nigdy nie
} 
Ideolodzy transhumanizmu również żywią wielką nadzieję, że rozwój nauk i biotechnologii umożliwi coraz sprawniejsze naprawianie i coraz większe ulepszanie naszej cielesności, dzięki czemu będziemy coraz sprawniejsi, zdrowsi i długowieczni. Jednak poszli oni o krok dalej - nie chodzi im już tylko o to, aby ulepszać ciało dane przez naturę, ponieważ wcześniej czy później dojdziemy do granicy takich działań. Należy zatem znaleźć sposób, aby nietrwałe ciało organiczne zastąpić trwalszym ciałem nieorganicznym. Myślenie (czy raczej: marzenie) transhumanistów biegnie dwutorowo: w kontekście badań biomedycznych i rozwijania biotechnologii oraz w kontekście badań nad ludzką świadomością. Z pierwszym z tych aspektów wiążą się nadzieje, że coraz lepsze poznawanie struktury genetycznej organizmów i coraz sprawniejsze metody inżynierii genetycznej umożliwią ciągłe ulepszanie ludzkiej cielesności, a więc eliminowanie chorób, wzmacnianie sił życiowych, wydłużanie życia. Transhumaniści tak jak Descartes traktują ciało ludzkie jako organiczną maszynę, której części można wzmacniać, naprawiać i ulepszać $^{25}$. A ponieważ wiedzą to, o czym Descartes nie wiedział - że mianowicie informacja o maszynie organicznej i zasadach jej działania zapisana jest w genach - więc ich nadzieje zdają się mieć nieporównanie bardziej solidne podstawy. Dzięki rozwojowi genetyki i biotechnologii będziemy niejako produkować coraz doskonalszych osobników ludzkich, a ponieważ wprowadzane na etapie płodowym zmiany genetyczne są dziedziczone, więc każde kolejne pokolenie będzie lepsze.

Drugi nurt myślenia transhumanistycznego determinowany jest faktem, że wszelkie ulepszanie musi dojść do ostatecznej bariery. Nie można w nieskończoność ulepszać materiału genetycznego, a przecież człowiek chce żyć nie tylko coraz dłużej, lecz pragnie żyć wiecznie. Aby to marzenie ziścić, należy to, co stanowi o człowieku - cały jego umysł, czyli świadomość, pamięć, psy-

zdarza się z winy duszy, a tylko dlatego, że jakiś główny organ ciała ulega zepsuciu”. Zob. René Descartes, Namiętności duszy, przeł. Ludwik Chmaj (Warszawa: PWN, 1958), 32.

${ }^{25}$ Aubrey de Grey, brytyjski biolog, przekonany, że pierwsza osoba, która dożyje kilkuset lat, już się narodziła, wyraża to wprost: „My approach is to start from the straightforward principle that our body is a machine. A very complicated machine, but nonetheless a machine, and it can be subjected to maintenance and repair in the same way as a simple machine, like a car". Cyt. za: Katarina Bradford, „A Brief on the Transhumanist Movement”, dostęp: 27.07.2018. https:// www.str.org/articles/a-brief-on-the-transhumanist-movement\#.WwGbJyAuCUk. 
chofizyczne cechy osobowej natury - przenieść z nośnika genetycznego na nieporównanie trwalszy nośnik nieorganiczny. A ponieważ tego rodzaju nośniki również nie są wieczne, należy opracować metodę sukcesywnego przenoszenia, przelewania (upload) umysłu na nośniki nieorganiczne ${ }^{26}$. Dzięki uzyskaniu takich możliwości człowiek stanie się nieśmiertelny ${ }^{27}$. Descartes niewątpliwie żywił nadzieję, że dostąpi nieśmiertelności w życiu przyszłym, w rzeczywistości zbawienia. Tym samym więc marzenia o nieśmiertelności ziemskiej uznałby za daremne i nierozsądne. Ale to właśnie zapoczątkowany dzięki jego filozofii rozwój wiedzy i technologii sprawił, że transhumaniści mogli uznać je za możliwe do spełnienia - wystarczyło przyjąć, że nie tylko ciało, ale także umysł (kartezjańskie ,ja”) jest maszyną. Swoisty mechanizm umysłowy to po prostu przepływ informacji między strukturami mózgu, a nasza świadomość to konstruowany przez mózg model działań świadomych $^{28}$. Transhumaniści uznali, że aby zachować świadomość na wieczność, a przynajmniej tak długo, jak ona będzie sobie tego życzyła, wystarczy zeskanować mózg.

${ }^{26}$ Wedle transhumanistów psychika człowieka jest wyznaczana przez jego cielesność, jednak elementy decydujące umiejscowione są w mózgu, zatem przeniesienie umysłu polegać ma na skopiowaniu mózgu. Kurzweil tak to wyjaśnia: „Kopiowanie ludzkiego mózgu oznacza skanowanie wszystkich jego najistotniejszych szczegółów, a następnie przenoszenie tych szczegółów na odpowiednio potężne podłoże obliczeniowe. Proces ten mógłby uchwycić całą osobowość osoby, jej pamięć, umiejętności i historię"; Kurzweil, Nadchodzi Osobliwość, 193.

${ }^{27}$ John Harris, profesor bioetyki z Uniwersytetu w Manchester, wiążący wielkie nadzieje z rozwojem genetyki, zauważa: „The Holy Grail of enhancement is immortality”; Harris, Enhancing Evolution. The Ethical Case for Making Better People, (Princeton and Oxford: Princeton University Press, 2007), 59. Ale też żadna inna teza transhumanistów nie jest tak ostro i zdecydowanie krytykowana, jak ta, że osiągniemy kiedyś nieśmiertelność. „L’immortalité appelée de voeux du transhumanisme est décidément le masque d'une haine de la vie. Détester la mort équivaut bel et bien à détester la vie, ce que sera parvenu à suggérer le dernier homme nietzschéen, réfractaire pêle-mêle au hasard, à l’imprévisible, à l'intensité et au risque."; Jean-Michel Besnier, „D’un désir mortifère d'immortalité. À propos du transhumanisme”, Cités 55 (2013), 22.

${ }^{28}$ Niemiecki kognitywista Thomas Metzinger, o którym stało się głośno dzięki jego koncepcji osoby jako procesu, wprawdzie nie jest uważany za transhumanistę, ale jego poglądy wpisują się w ideologię transhumanistyczną. Twierdzi on: „We are Ego Machines, natural informationprocessing systems that arose in the process of biological evolution on this planet. The Ego is a tool - one that evolved for controlling and predicting your behavior and understanding the behavior of others"; tenże, The Ego Tunnel. The Science of the Mind and the Myth of the Self (New York: Basic Books, 2009), 207. 


\subsection{Ulepszanie psychiki}

Na sferę ludzkiej psychiki składają się zarówno władze intelektualne, jak i akty woli oraz stany i działania emocjonalne. Descartes przypisywał władze intelektualne wyłącznie duszy (umysłowi), co było konsekwencją dokonanego przezeń ścisłego rozdziału między substancją duchową (myślową) a substancją materialną (cielesną) i przyznania im całkowitej autonomii. W wypadku człowieka swoistym podłożem autonomiczności sfery duchowej jest samoświadomość, a ponieważ w akcie samoświadomości podmiot doświadcza siebie wyłącznie jako myślącego (jako myślącą jaźń), dlatego właśnie myślenie zostaje uznane za jedyną właściwość duszy (umysłu). Umysł myśli autonomicznie, a choć zarówno tok myślenia, jak i jego jakość zależą od stanu i oddziaływań ciała, jest to zależność jedynie zewnętrzna ${ }^{29}$. Wyrażając swoją nadzieję, że rozwój nauki prowadzić będzie do zwiększania mocy ludzkiego intelektu, Descartes nie mógł oczywiście rozumieć przez to jakichkolwiek działań na duszy - jedynie wyrażał przekonanie, że drogą ulepszania ludzkiego ciała dochodzić będziemy do osłabiania negatywnych wpływów niedostatków i zaburzeń fizjologicznych na procesy myślowe. Innymi słowy, ulepszanie cielesności nie powoduje ulepszania umysłowości, lecz zmniejsza lub eliminuje to, co może zakłócać myślenie. A prawidłowe myślenie kieruje wolę człowieka na właściwe drogi.

Inaczej przedstawia się zależność między jakością cielesności a emocjonalnością człowieka. Omawiając zagadnienia fizjologii, Descartes rozróżniał procesy dokonujące się bez udziału umysłu, takie jak bicie serca, oddychanie czy trawienie, i procesy wymagające współdziałania umysłu i ciała. Do tego drugiego rodzaju procesów należą szeroko rozumiane uczucia. Wedle Descartes’a są one modyfikacjami duszy, czyli są myślami, a więc należą wyłącznie do duszy. Jednak uczucia nie są rezultatem autonomicznej aktywności duszy, lecz są doznaniami duszy spowodowanymi przez ciało. Descartes’a teoria uczuć opiera się więc na dwu zasadach: na zasadzie przyczynowości substan-

\footnotetext{
${ }^{29}$ Pojawia się znany problem trudności z wyjaśnieniem na gruncie kartezjanizmu, na czym polega zasada jedności psychofizycznej człowieka. Kwestii tej nie musimy tu rozważać. Omówienie kartezjańskiego rozumienia interakcji umysłu i ciała znaleźć można w: Amélie Oksenberg Rorty, „Descartes on Thinking with Body”, w: The Cambridge Companion to Descartes, red. John Cottingham (Cambridge: Cambridge University Press, 1995), 371-392.
} 
cjalnej, która głosi, że uczucia, będąc modyfikacjami duszy, należą wyłącznie do duszy, i na zasadzie przyczynowości, zgodnie z którą powstawanie uczuć w duszy ma swe źródła wyłącznie w ciele ${ }^{30}$. Wynika $\mathrm{z}$ tego wniosek, że ulepszająca zmiana mechanizmów ludzkiego ciała skutkować będzie ulepszeniem ludzkiej psychiki, czyli wygaszaniem złych i wzmacnianiem dobrych emocji oraz uszlachetnieniem uczuć.

Przekonanie, że odpowiednia zmiana ludzkiego ciała doprowadzi do ulepszenia ludzkiej sfery psychicznej, jest na gruncie transhumanizmu uznawane za oczywiste. Transhumaniści zdają się jednak przywiązywać zdecydowanie większą wagę do zwiększania mocy ludzkiego (czy raczej: postludzkiego) intelektu niż do ulepszającego modyfikowania genetycznego ludzkiej sfery wolitywnej i emocjonalnej. Skoro myślenie jest generowane przez cielesność, to ulepszając cielesność, ulepszamy myślenie. Wiązane z rozwojem genetyki i inżynierii genetycznej nadzieje na maksymalne ulepszenie ludzkiej cielesności, a następnie przeniesienie osobowej psychiki na nowe, niebiologiczne nośniki, prowadzą do przekonania, że równolegle i w powiązaniu z tymi procesami dokonywał się będzie niewiarygodny wzrost mocy ludzkiego (postludzkiego) intelektu ${ }^{31}$. Siła myślenia i efektywność zdolności intelektualnych przyszłego człowieka ma być tak wielka, że nawet nie potrafimy jej sobie teraz wyobrazić i możemy jedynie określać tę przyszłą inteligencję jako sztuczną, choć dla nowych ludzi będzie to inteligencja naturalna ${ }^{32}$.

Problem ulepszania sfery emocjonalnej transhumaniści widzą w szerszym kontekście zmieniania ludzkiego genotypu oraz tworzenia powiązań mózgowo-komputerowych. Stosowne modyfikacje genetyczne i hybrydyzacja cielesno-elektroniczna mają doprowadzić nie tylko do trwałego stanu zdrowia fizycznego, czyli harmonijnie i bez zakłóceń działającej fizjologii, lecz także do zharmonizowania ludzkiej sfery emocjonalnej, czyli wygaszenia emocji

\footnotetext{
${ }^{30}$ Zob. Ferdinand Alquié, Kartezjusz, przeł. Stanisław Cichowicz (Warszawa: Pax, 1989), 144.

31 „Nowe przyszłe, zasadniczo niebiologiczne »ja « będą znacznie bardziej inteligentne, a tym samym będą w znacznie większym stopniu prezentować myśl ludzką najlepszej jakości”; Kurzweil, Nadchodzi Osobliwość, 371.

${ }^{32}$ Mówiąc o sztucznej inteligencji (SI), wyrażamy przez to jedynie naszą niemożność pojmowania, czym nowa inteligencja będzie w swej istocie. Jak twierdzi Kurzweil, „mocna SI wyłania się z wielu różnorodnych wysiłków i będzie głęboko wpisana w infrastrukturę naszej cywilizacji. Prawdę mówiąc, w przyszłości będzie ona zagnieżdżona w naszych ciałach i mózgach. Tym samym będzie odzwierciedlać nasze wartości, ponieważ będzie nami samymi”; tamże, 411.
} 
złych (np. agresji czy zawiści), wzmocnienia emocji pozytywnych (np. empatii czy altruizmu), a także wzbogacenia zakresu pozytywnych doznań emocjonalnych ${ }^{33}$. Transhumaniści posuwają się nawet do przypuszczenia, iż możliwe będzie danie człowiekowi nowych, dotąd mu nieznanych doznań i ekspresji emocjonalnych, które wzbogacą jego życie psychiczne. Te nowe stany psychiczne i możliwości emocjonalne, których neurologiczna maszyneria ludzkiego mózgu nie rozwinęła w procesie ewolucyjnym, a więc których my nie potrafimy nawet sobie wyobrazić, mogą zostać przez przyszłych ludzi uznane za bardzo użyteczne i bardzo cenne ${ }^{34}$. Transhumaniści mają więc nadzieję na ulepszenie ludzkiej sfery psychicznej w stopniu, o jakim Descartes zapewne nigdy nie pomyślał; jednak różnica między nimi a nim jest jedynie różnicą co do stopnia, nie co do istoty.

\subsection{Ulepszanie moralności}

Trzecią część Rozprawy o metodzie rozpoczyna Descartes wskazaniem, że zanim zburzymy stary dom, aby postawić nowy, powinniśmy zapewnić sobie jakieś mieszkanie na czas budowy. On miał zamiar zburzyć stary gmach wiedzy i zbudować nowy; a zarazem sądził, że nowa wiedza wygeneruje nową moralność. Zanim więc powstanie etyka nowa - a Descartes był przekonany, że to on wniesie znaczący wkład w jej tworzenie - potrzebna będzie jakaś moralność zastępcza, ta bowiem, którą kierujemy się obecnie, zawiera zbyt wiele błędów, jest za bardzo wieloznaczna i niejasna. Dlatego filozof postanowił urobić sobie „moralność tymczasową”, zgodnie z którą kroczył będzie przez życie, budując gmach nowej nauki. Dotychczasowa moralność two-

\footnotetext{
33 „Technologies such as brain-computer interfaces and neuropharmacology could amplify human intelligence, increase emotional well-being, improve our capacity for steady commitment to life project or a loved one, and even multiply the range and richness of possible emotions"; Nick Bostrom, The Transhumanist FAQ. A General Introduction. Version 2.1 (2003), dostęp: 27.07.2018. https://nickbostrom.com/views/transhumanist.pdf.

${ }^{34}$ Jak wskazuje Bostrom, ,there might also be entirely new psychological states and emotions that our species has not evolved the neurological machinery to experience, and some of these sensibilities might be ones we would recognize as extremely valuable if we became acquainted with them”; Bostrom, „Why I Want to be a Posthuman When I Grow Up”, w: Medical Enhancement and Posthumanity, red. Bert Gordijn, Ruth Chadwick (Dordrecht: Springer, 2008), 107-136; cyt. za: https://nickbostrom.com/posthuman.pdf, dostęp 27.07.2018.
} 
rzona była na drodze empirycznej, jest rezultatem doświadczeń życiowych człowieka, zawiera mnóstwo norm i zaleceń o różnym stopniu wartości i zasadności. Moralność tymczasowa ma również charakter empiryczny, ale ponieważ ma służyć doraźnym celom, składa się z kilku zaledwie zasad, przez samego filozofa wybranych i racjonalnie uzasadnionych. Przyszła moralność będzie ostateczną etyką racjonalną, co można już teraz uzasadnić, wskazując, że i obecna etyka jest słuszna i użyteczna jedynie w tej mierze, w jakiej podlega racjonalnemu uzasadnieniu ${ }^{35}$. Nowemu systemowi etycznemu, stanowiącemu swoistą emanację przyszłej wiedzy, przysługiwać będzie walor pewności metafizycznej.

Descartes rozróżniał pewność moralną, czyli pragmatyczną, wystarczającą na potrzeby życia codziennego, i pewność metafizyczną, czyli opartą na niewzruszonych podstawach rozumowych, a więc ostateczną. Obecnie ani wiedza, ani moralność jeszcze nie mają waloru pewności metafizycznej, jednak Descartes miał mocne i niezachwiane przekonanie, że rozwój nauk musi doprowadzić do uzyskania przez nie pewności metafizycznej i dzięki temu do wyłonienia się nowej etyki - racjonalnej i ostatecznej. Całą filozofię, czyli całość wiedzy ludzkiej, przedstawiał jako drzewo, którego korzenie tworzy metafizyka, pień - fizyka, a konarami są pozostałe nauki, sprowadzające się do trzech podstawowych: medycyny, mechaniki i etyki. Nowa etyka stworzona zostanie dzięki rozwojowi nauk i będzie ostatnim stopniem mądrości ${ }^{36}$. Dzięki medycynie człowiek miał uzyskać lepszą psychikę, więc można domniemywać, że na jej gruncie emocje zostaną podporządkowane rozumowi i przestaną być przeszkodą w procesie tworzenia racjonalnej etyki. Descartes nie postawił pytania, czy dojście do moralności ostatecznej i niezmiennej będzie rezultatem osiągnięcia ostatniego stopnia rozwoju wiedzy, od którego

\footnotetext{
${ }^{35}$ Descartes twierdził, że wola podąża za daną rzeczą albo jej unika, w zależności od tego, czy rozumowanie przedstawia ją jako dobrą, czy jako złą: „wystarcza więc sądzić właściwie, by czynić dobrze, a sądzić najlepiej jak można, by czynić też to, co da się najlepszego, to znaczy, by zdobyć wszelkie cnoty, a zarazem wszelkie pozostałe dobra nam dostępne"; Descartes, Rozprawa o metodzie, 33. Podobnie twierdził później Pascal, który sytuując godność człowieka w myśleniu, wzywał: „Silmy się tedy dobrze myśleć: oto zasada moralna”; Blaise Pascal, Myśli, nr 264 w układzie Chevaliera, przeł. Tadeusz Żeleński (Boy) (Warszawa: Pax, 1977), 113.

${ }^{36}$ W liście do ks. Picota, tłumacza Zasad filozofii na język francuski, Descartes wyjaśniał: „mam tu na myśli najwyższą i najdoskonalszą etykę, która zakłada całkowitą znajomość innych nauk i jest ostatnim stopniem mądrości”; Descartes, Zasady filozofii, 367.
} 
już ani nauki, ani moralność rozwijać się nie będą, albowiem wszystko już będziemy wiedzieli o świecie, o człowieku i o tym, jak mamy zachowywać się wobec świata, wobec samych siebie i wobec siebie nawzajem.

Postulat nowej moralności, która zastąpi dotychczasową - tak bardzo niepewną, zwodniczą i niewystarczającą wobec wyzwań stawianych przez życie jest wspólny Descartes'owi i transhumanistom. Wspólne jest też przekonanie, że to rozwój wiedzy doprowadzi do nowej moralności. Zważyć jednak należy, iż wiedza naukowa nie rozwija się sama $z$ siebie, tylko jest rozwijana przez ludzi posługujących się rozumem; tak samo nowa moralność nie wyłoni się sama $\mathrm{z}$ rozwijającej się wiedzy, lecz będzie dziełem rozumu ludzkiego. W tym punkcie ujawnia się istotna różnica. Descartes sądzi, że rozwój nauk czynił będzie ludzi mądrzejszymi, dzięki czemu będą mogli oni wyrozumować sobie moralność będącą najwyższym stopniem mądrości. Transhumaniści sądzą, że postęp naukowy pozwoli nam coraz lepiej rozumieć, jaka moralność jest nam potrzebna, a rozwój biotechnologii umożliwi nam niejako zaszczepienie w ludziach tej nowej moralności. Tworzenie nowej moralności będzie więc konieczną konsekwencją przejęcia przez człowieka procesu ewolucji własnego gatunku. Rozwój wiedzy prowadzi do tego z konieczności, a zatem z konieczności zmieniać się będzie nasza moralność i my sami modyfikować będziemy dotychczasowe zasady moralne, jak też wprowadzać nowe ${ }^{37}$. Różnica między Descartes’em a transhumanistami również w tej kwestii okazuje się jedynie różnicą stopnia i gdyby ojciec nowożytnego racjonalizmu zyskał wgląd w stan współczesnej nam wiedzy, zapewne doszedłby do tych samych wniosków.

Co więcej, zarówno Descartes, jak i transhumaniści opierają przekonanie o możliwości osiągnięcia doskonałej moralności na uznaniu stanowiska intelektualizmu etycznego, zgodnie z którym uzyskanie przez jednostkę wiedzy

\footnotetext{
${ }^{37}$ Angielski biolog Julian Huxley, pionier ideologii transhumanizmu i twórca nazwy „transhumanizm”, mocno podkreślał obiektywną konieczność kierowania przez człowieka rozwojem własnego gatunku. „Czegokolwiek człowiek chce bądź nie chce, czy jest świadom tego, co robi, czy nie, w rzeczy samej, determinuje on przyszły kierunek ewolucji na tej ziemi. To jest przeznaczenie, od którego nie da się uciec, a im wcześniej się to skonstatuje i zacznie się w to wierzyć, tym lepiej będzie dla wszystkich, których to dotyczy”; Julian Huxley, „Transhumanizm”, przeł. Marta Soniewicka, Ethics in Progress 6, 1 (2015), 18. Słowa te zostały napisane ponad 60 lat temu.
} 
o dobru nieodparcie skłania ją do kierowania się nim. Intelektualizm etyczny głosi, że jeżeli człowiek czyni zło, to dlatego, że nie wie, iż jego czyn jest zły. A zatem cnoty można się nauczyć - zgodnie twierdzą Descartes i transhumaniści; ci drudzy dodają, że oprócz działań kształcących i wychowujących można i należy stosować działania inżynierii genetycznej. Transhumaniści rozumieją ulepszanie moralne człowieka jako wyposażanie go w dyspozycje i wytwarzanie w nim skłonności, dzięki którym będzie on mógł dochodzić do właściwego rozumienia, co jest dobre, słusznie i właściwe, jak też będzie działał zgodnie $\mathrm{z}$ tym rozumieniem ${ }^{38}$. Zmierzamy ku stworzeniu nowego gatunku ludzkiego - ludzi tak dalece innych od nas, że nasze rozumienie tego, co dobre, i tego, co złe, do nich już nie będzie się stosowało. Jednak transhumaniści nie muszą bezwarunkowo wyznawać doktryny intelektualizmu etycznego jeżeli okaże się, że jakaś część ludzi wprawdzie wie, co jest dobre, a jednak skłania się ku złu, dla transhumanisty stanie się to potwierdzeniem wskazania, aby przeprowadzać stosowną modyfikację ich materiału genetycznego. Tym samym transhumanista faktycznie zakłada, że jakaś część ludzi, która posiada wiedzę o dobru i złu, jest uprawniona, aby tę wiedzę wszczepić innym za pomocą metod bioinżynierii ${ }^{39}$. Descartes wierzył, iż dzięki rozwojowi wiedzy ludzie będą znali dobro i zło; transhumaniści wierzą, że dzięki rozwojowi wiedzy decydować będą, co jest dobrem, a co złem, i te decyzje staną się obowiązujące dla całej ludzkości.

\section{Dziedzictwo kartezjańskie}

Descartes jest prekursorem transhumanizmu nie dlatego, jakoby transhumaniści świadomie korzystali z jego ustaleń i odwoływali się do jego tez,

\footnotetext{
38 „To be morally enhanced is to have those dispositions which make it more likely that you will arrive at the correct judgement of what it is right to do and more likely to act on that judgement”; Julian Savulescu, Ingmar Persson, „Moral Enhancement, Freedom, and the God Machine”, The Monist 95, 3 (2012), 406.

${ }^{39}$ "It is disputed what the right thing to do is and how we would arrive at the right course of action. What constitutes moral enhancement will depend on the account one accepts of right action"; tamże.
} 
lecz w sensie zasadniczo głębszym. Kartezjańska nowa filozofia przestawiła na nowe tory badania naukowe, zapoczątkowując rozwój przyrodoznawstwa w stopniu nieporównywalnym z minionymi epokami. Odseparowanie rzeczywistości duchowej od materialnej, wyposażenie tej drugiej we własne prawa rozwoju i działania oraz związane $\mathrm{z}$ tym odrzucenie spekulacji filozoficznej z jednej strony okazało się bardzo skuteczne w badaniach przyrodniczych, z drugiej zaś ukazało brak potrzeby uwzględniania w jakiejkolwiek mierze czynników duchowych w procesie poznawania przyrody. Sam Descartes wbrew własnym intencjom potwierdzał zasadność takiej postawy, wskazywał bowiem na kategorie matematyki i mechaniki jako właściwe opisowi i penetracji sfery materialnej, nie wskazał jednak żadnego zestawu kategorii odnoszących się do sfery ducha. Musiało to zrodzić przypuszczenie, że walor poznawczy ma jedynie część fizykalna jego przemyśleń i ustaleń, cała metafizyka natomiast jest jałowa i bezpłodna. Tendencje do uznania jedynie „fizyki” Descartes’a i odrzucenia metafizyki jako naukowo bezużytecznej pojawiły się jeszcze za życia filozofa, zaczęły dominować w następnym stuleciu, a od XIX wieku poczynając, nauki przyrodnicze wyzbyły się wszelkich aspektów metafizycznych ${ }^{40}$.

Zazwyczaj podkreśla się, że dzięki radykalnemu oddzieleniu substancji duchowej od substancji cielesnej autonomiczne w swych działaniach ciało mogło stać się przedmiotem rzetelnych badań naukowych. Jest to oczywiście prawdą, ale należy też zwrócić uwagę na fakt, że kartezjańska fizyka rozumiana była szeroko - jako całość wiedzy o przyrodzie. Przyroda zaś pojęta została mechanistycznie, a to faktycznie zacierało granicę między tym, co organiczne, a tym, co biologiczne ${ }^{41}$. Samo życie w sensie biologicznym prze-

\footnotetext{
${ }^{40}$ Swoistym posumowaniem tego procesu jest wydana w 1949 roku książka Gilberta Ryle’a The Concept of Mind, w której autor podjął się obalenia kartezjańskiego „mitu o duchu w maszynie”. Zob. Gilbert Ryle, Czym jest umysł, przeł. Witold Marciszewski (Warszawa: PWN, 1970). Ryle argumentuje, że Descartes nieprawnie nadał procesom umysłowym status substancjalny i charakter mechanistyczny. Argumentacja ta wpisana jest w koncepcję filozofii analitycznej autora, jednak bazuje na tezie wspólnej dominującej większości przyrodników - że mianowicie wyjaśniając zjawiska psychiczne, nie musimy odwoływać się do jakkolwiek pojętej sfery duchowej.

${ }^{41}$ Zob. bardzo obszerny artykuł: Andrés Vaccari, „Dissolving Nature. How Descartes Made Us Posthuman", Techné. Reseach in Philosophy and Technology" 16, 2 (2012), 138-186. Autor szczegółowo omawia swoistą "mechanizację” życia dokonaną przez Descartes’a, który jako
} 
staje mieć odrębny, sobie właściwy sens i staje się jedynie teoretyczną konstrukcją tworzoną i opisywaną w kategoriach mechaniki ${ }^{42}$. Odseparowanie duszy (samoświadomości) od ciała nie tylko doprowadziło więc do odrzucenia pojęcia substancjalnej duszy, czyli do uznania, że cała psychika człowieka jest wytworem czy epifenomenem ciała, ale także uczyniło nieistotną kwestię, jaki jest nośnik tej psychiki, skoro nie istnieje nieprzekraczalna granica między organicznym a nieorganicznym. Właśnie na tej podstawie transhumaniści zakładają, że samoświadomość - szerzej: samowiedza człowieka - może być „przelana” w sieć.

Z punktu widzenia niniejszych rozważań istotne znaczenie miał też fakt, że odrzucenie metafizyki Descartes’a było zarazem odrzuceniem jego wielkiego marzenia, iż rozwój wiedzy doprowadzi do powstania nowej etyki, wyrażającej moralność będącą ostatnim stopniem mądrości. To marzenie mogło narodzić się jedynie na gruncie przekonania o jedności duchowo-materialnej człowieka. Ale Descartes tej jedności nie potrafił wyjaśnić, przede wszystkim zaś wcześniej czy później musiało stać się oczywiste, że w metodologię nauk nie jest wpisana etyka. Kolejne osiągnięcia nauki i technologii bynajmniej nie przybliżyły nas do zrealizowania tego marzenia i równie daleko nam do ostatecznej mądrości, jak daleko było do niej ludziom minionych epok. Im większe są nasze możliwości dzięki nauce i technologii, tym bardziej skłonni jesteśmy sądzić, że rozwój wiedzy naukowej nie ulepsza naszej moralności. Wprawdzie nigdy przedtem ludzie, przynajmniej w cywilizacji zachodniej, nie żyli tak długo, zdrowo i dostatnio, ale nie zmniejsza to lęku przed zagro-

pierwszy „extended the mechanization of the heavens into the heart of life”; tamże, 139. W ten sposób, twierdzi Vaccari, Descartes uczynił pierwszy krok na drodze prowadzącej do stworzenia postczłowieka.

${ }^{42}$ W konsekwencji także nauka nie jest już motywowanym pasją poznawczą badaniem obiektywnej rzeczywistości, a staje się instrumentem, za pomocą którego człowiek uzyskiwać może praktyczne korzyści. „Descartes's vision for the sciences is technological in another sense: not just in terms of mastery, but in the sense that science itself is instrumental, since its ultimate purpose is utility and material efficaciousness"; tamże, 164. Kwestia, jaki sens ma na gruncie filozofii Descartes’a kategoria życia, jest dość szeroko dyskutowana; zob. np. Barnaby R. Hutchins, "Descartes and the Dissolution of Life”, The Southern Journal of Philosophy” 54, 2 (2016), 155-173, oraz tenże, „Does Descartes Have a Principle of Life? Hierarchy and Interdependence in Descartes's Physiology”, Perspectives on Science 24, 6 (2016), 744-769. Zob. także bardzo eksplikatywny tekst: Ann Wilbur Mackenzie, „A Word about Descartes' Mechanistic Conception of Life", Journal of the History of Biology 8, 1 (1975), 1-13. 
żeniami, jakie mogą pojawić się właśnie ze strony nauki i technologii ${ }^{43}$. A zarazem zdajemy sobie sprawę, że nie jesteśmy w stanie powstrzymać rozwoju nauki i technologii mocą własnych świadomych decyzji motywowanych racjami etycznymi - rozwój wiedzy naukowej i kolejne stopniowe wdrażania nowych technologii są nieuchronne ${ }^{44}$. Świadomość tej nieuchronności zwiększa obawy i wzmacnia lęki.

Ideologia transhumanizmu sprzeciwia się tej pesymistycznej postawie, a tym samym podejmuje na nowo marzenia kartezjańskie. Ponieważ rozwój wiedzy i umiejętności jest konieczny i nieuchronny, to naszym moralnym obowiązkiem staje się umiejętne kierowanie nim i właściwe korzystanie z jego owoców ${ }^{45}$. Przy nieprzerwanym rozwoju wiedzy musi nadejść czas, w którym zaczniemy przy pomocy środków biotechnologicznych zarówno

${ }^{43}$ Przytoczmy bardzo pesymistyczną wypowiedź jednego z najwybitniejszych polskich filozofów współczesnych: „Staczamy się jakby po pochylni: wszystko, co nauka może wiedzieć, nauka musi wiedzieć, i podobnie - wszystko, co technika może zrobić, prawdopodobnie zrobi. [...] ludzkie możliwości zmieniania i kierowania przyrodą wzrastają szybciej, aniżeli człowiek jest w stanie wyobrazić sobie konsekwencje głębokich przemian, jakie jest w stanie wywołać"; [Józef Bańka], „O swoim filozofowaniu mówi prof. dr hab. Józef Bańka”, ¿OФIA 9, (2009), 312.

${ }^{44}$ Stanisław Lem (1921-2006), wybitny pisarz i głęboki myśliciel, wielokrotnie powtarzał, że „technologia jest zmienną niezależną naszej cywilizacji”; Lem, Moloch (Warszawa: Agora, 2010), 346. Znaczy to, że sposób i kierunek tworzenia technologii jest faktycznie od człowieka niezależny, a więc to nie człowiek w istocie decyduje o charakterze technologii, lecz technologie zmieniają charakter człowieka. „Nie ufam żadnym przyrzeczeniom, nie wierzę w zapewnienia podbudowane tak zwanym humanizmem. Jedynym sposobem na technologię jest inna technologia. Człowiek wie dzisiaj więcej o swoich niebezpiecznych skłonnościach, niż wiedział sto lat temu, a za następnych sto lat wiedza jego będzie jeszcze doskonalsza. Uczyni z niej wówczas użytek"; tenże, Summa technologiae (Warszawa: Agora, 2010), 8. Faktycznie Lem przyznaje, że ideologia transhumanizmu będzie wprowadzania w życie niejako z konieczności. Transhumaniści też tak twierdzą, wskazując, że historia ludzkości dowodzi, iż różnorodne katastrofalne wydarzenia wprawdzie przerywały czasowo lub spowalniały rozwój naukowo-technologiczny, ale nie zahamowały go całkowicie. „Nawet tak epokowe wydarzenia jak dwie wojny światowe [...], zimna wojna oraz liczne wstrząsy gospodarcze, kulturowe i społeczne nie były w stanie spowodować najmniejszego uszczerbku w tempie rozwijania się trendów technologicznych"; Kurzweil, Nadchodzi Osobliwość, 367.

${ }^{45}$ Nick Bostrom tak rozpoczyna swoją historię transhumanizmu: „The human desire to acquire new capacities is as ancient as our species itself. We have always sought to expand the boundaries of our existence, be it socially, geographically, or mentally. There is a tendency in at least some individuals always to search for a way around every obstacle and limitation to human life and happiness"; Bostrom, A History of Transhumanist Thought, 1. Por. idem, The Transhumanist FAQ. Bostrom sądzi zarazem, że realizowanie tego pragnienia poprzez co- 
ulepszać naszą cielesność, jak i ukierunkowywać zmiany naszej moralności. Być może Descartes skłonny byłby uznać, że jest to konieczność wpisana w naturę ludzką przez Opatrzność; transhumaniści sądzą, że jest to konieczność narzucona gatunkowi ludzkiemu przez bezosobową siłę ewolucji. Descartes niewątpliwie rozumiał słowa szatana z Księgi Rodzaju jako potwierdzenie, że popełnienie grzechu pierworodnego dało człowiekowi znajomość dobra i zła; transhumaniści uznali, że to sam człowiek decyduje, co jest dla niego dobre, a co złe.

A skoro rozwój wiedzy jest rozwojem ciągłym i nie ma naturalnych granic, więc i doskonalenie przyrody oraz człowieka również nie jest z natury ograniczone. Wprawdzie Descartes nie powiedział tego wprost, ale warto zwrócić uwagę na pewien znamienny fragment z Medytacji o pierwszej filozofii.

Nie mogę się [...] uskarżać, że otrzymałem od Boga wolę, czyli wolność decyzji o niedostatecznym zasięgu i doskonałości, bo wiem z doświadczenia, że rzeczywiście nie posiada ona żadnych granic. I wydaje mi się rzeczą ze wszech miar godną uwagi, że wszystko inne, co jest we mnie, nie jest ani tak wielkie, ani tak doskonałe, bym nie mógł pomyśleć, że mogłoby być jeszcze większe czy doskonalsze ${ }^{46}$.

Descartes faktycznie stwierdza, przynajmniej implicite, że nie istnieje granica doskonalenia ludzkiej natury. Można by z powyższego i z owej nadziei, którą wiązał z rozwojem nauk, wyprowadzić wniosek, że rozwój wiedzy umożliwi stałe zwiększanie ludzkich możliwości ${ }^{47}$.

To samo w istocie twierdzą transhumaniści. Ale oni wskazują na coś, o czym Descartes zapewne nigdy nie pomyślał. Przecież stale przyspieszający

raz dalej idące ulepszanie przyrody i człowieka jest praktyczną realizacją ludzkiej godności: "Changing nature for the better is a noble and glorious thing for humans to do"; tamże.

${ }^{46}$ René Descartes, Medytacje o pierwszej filozofii, przeł. Maria i Kazimierz Ajdukiewiczowie (Warszawa: PWN, 1958), 1:75.

${ }^{47}$ Tę nadzieję na permanentne zwiększanie naszych możliwości przejęła epoka oświecenia. Condorcet w swych rozważaniach o możliwościach doskonalenia się rodzaju ludzkiego nie tylko wyraża przekonanie, że proces „udoskonalania samej naturalnej konstytucji człowieka” będzie się dokonywał, ale nadto przekonuje, iż całe doświadczenie ludzkości świadczy, że „natura nie wyznaczyła żadnego kresu naszym nadziejom i możliwościom”; Antoine Nicolas Condorcet, Szkic obrazu postępu ducha ludzkiego poprzez dzieje, przeł. Bohdan Suchodolski (Warszawa: PWN, 1957), 213. 
rozwój wiedzy i technologii musiałby w pewnym momencie doprowadzić do sytuacji, w której ludzkie myślenie nie byłoby już zdolne nadążać za tym rozwojem; inaczej mówiąc, naturalne tempo rozwoju nauki jest szybsze niż naturalne tempo rozwoju ludzkich zdolności intelektualnych, a więc istnieje teoretyczny punkt, od którego poczynając, wiedza zwiększa się szybciej, niż zwiększa się moc ludzkiego myślenia. Zatem ludzkie myślenie musi zostać wzmocnione, nauka z konieczności doprowadzi do powstania nowego człowieka, niejako na swoją miarę. Jeden z najbardziej znaczących transhumanistów stawia szereg retorycznych pytań.

Czy tempo rozwoju technologicznego może przyspieszać bez końca? Czy nie ma punktu, w którym ludzie nie będą już zdolni myśleć wystarczająco szybko, by nadążyć za tym tempem? W przypadku nieulepszonego człowieka jest to jasne. Co jednak osiągnęłoby tysiąc naukowców, z których każdy byłby tysiąc razy inteligentniejszy niż dzisiejsi naukowcy i działał tysiąc razy szybciej niż współcześni ludzie (ponieważ przetwarzanie informacji w ich w głównej mierze niebiologicznych mózgach byłoby szybsze)? [...] Co mogliby wymyślić? ${ }^{48}$

O ile Descartes jedynie uświadamiał sobie, że nie posiada żadnej cechy czy właściwości, co do której nie potrafiłby pomyśleć, iż mogłaby być zwiększona lub udoskonalona, o tyle transhumaniści zdają się domniemywać, że nie posiadają żadnej takiej cechy czy właściwości, co do której mogliby sądzić, iż nie musi być zwiększana lub udoskonalana.

Kartezjańskie dualistyczne rozumienie natury ludzkiej nie zostaje, jak mogłoby się wydawać, odrzucone przez transhumanistów, lecz inaczej zinterpretowane. Descartes mylił się, sądząc, że ciało i dusza są substancjami różnymi w sensie ontologicznym, jednak jego intuicja była dobra, mimo iż on sam nie był tego świadom. Ciało i dusza to dwa rodzaje materii, z których pierwsza jest nam dostępna bezpośrednio, druga zaś jedynie pośrednio, poprzez swoje przejawy; analogicznie do występującej we wszechświecie materii i energii, której doświadczamy zmysłowo, i tzw. ciemnej materii i energii, której nie możemy obserwować, ale której istnienie wyjaśnia obserwowalne efekty grawitacyjne $^{49}$. Dlatego właściwie rozumiany kartezjański dualizm nie jest pro-

\footnotetext{
${ }^{48}$ Kurzweil, Nadchodzi Osobliwość, 37.

${ }^{49}$ Adam Drozdek, „On Cyberimmortality”, Analiza i Egzystencja 31 (2015), 16-17.
} 
blemem, lecz początkiem rozwiązania problemu - daje ontyczne podstawy modyfikacji zarówno ludzkiej cielesności, jak i ludzkiej duchowości. Simon Young, żywiący niezłomne przekonanie o możliwości skanowania ludzkiego mózgu w celu zapewnienia człowiekowi nieśmiertelności, powiada wprost, że kartezjański dualizm wskazuje początek ewolucji gatunku ludzkiego od Homo sapiens do Homo cyberneticus - człowieka, który staje się sternikiem swego przeznaczenia ${ }^{50}$.

Jeśli transhumaniści nie powołują się na Descartes'a jako swego prekursora, mimo iż są jego spadkobiercami, to dlatego, że nieporównanie większe są ich marzenia i oczekiwania. Ten rozwój nauk, którego oni są świadkami, a którego Descartes zapewne nie byłby w stanie sobie skonkretyzować w wyobraźni, daje im poczucie, że choć mają swoich poprzedników, to żaden z nich nie miał i mieć nie mógł wizji tak wielkiej i tak śmiałej, jaką mają oni. W szczególności Bacon i Descartes - dwaj myśliciele i badacze stojący u początków nauki nowożytnej - nie byli zdolni do sformułowania i postawienia przed nauką tak wielkich oczekiwań. Max More wyjaśniał to wskazaniem, że Bacon i Descartes jedynie usiłowali zdobyć jak największą wiedzę i dojść do jak największych umiejętności, w przekonaniu, że dzięki temu ulepszą świat i człowieka, czyli to przewidywany rozwój wiedzy generował ich marzenia o ulepszaniu przyrody i człowieka. Oni zaś w kontekście współczesnego rozwoju nauki i technologii swymi marzeniami wyprzedzają ten rozwój i wpływają na jego kierunek ${ }^{51}$. Być może tak jest rzeczywiście. W niczym to oczywiście nie umniejsza zasług wspomnianych dwu wielkich postaci, jak też nie może odebrać Descartesowi miana prekursora transhumanizmu. Trans-

${ }^{50}$ "Cartesian duality marks the beginning of human evolution from Homo sapiens to Homo cyberneticus - man the steersman of his own destiny”; S. Young, Designer evolution: A Transhumanist Manifesto (Amherst: Prometheus Books, 2006), 34. Cytowane za: Adam Drozdek, „On Cyberimmortality”, 17.

${ }^{51}$ Max More twierdzi, że jego (i w ogóle transhumanistów) postawa jest postawą racjonalną. Jednak racjonalizm Bacona czy Descartes’a określa jako „konstruktywny”, czyli tworzący coś na bazie zdobytej wiedzy, podczas gdy jego racjonalizm jest „krytyczny”, czyli przewidujący i wytyczający kierunek rozwoju nauki. „Critical rationalism distinguishes us from Bacon who, like Descartes, believed that the path to genuine knowledge lay in first making a comprehensive survey of what is reliably known rather than merely believed”; Max More, „H+: True Transhumanism”, dostęp: 27.07.2018. http://www.metanexus.net/essay/h-true-transhumanism. 
humaniści wyruszają z tego samego punktu, co Descartes, i do tego samego celu zmierzają. A krocząc tą samą drogą, nie porzucają Descartes'a, lecz go przekraczają. Dlatego transhumanizm może być określany jako transkartezjanizm.

Postawmy na zakończenie pytanie, jak daleko zaprowadzić nas może realizacja kartezjańskiego marzenia o ulepszaniu świata i człowieka. Podstawą ideologii transhumanizmu są dwie przesłanki. Pierwsza z nich to teza, że rozwój nauki i technologii dokonuje się z konieczności i nie może sam z siebie trwale się zatrzymać. Druga natomiast głosi, że ludzkie pragnienie jak najdłuższego, może nawet wiecznego, życia w pełnym dobrostanie psychofizycznym jest naturalną cechą rodzaju ludzkiego, a tym samym nadzieja dotycząca działań zmierzających do tego celu zawsze okazywać się będzie silniejsza od obaw z tym związanych. Z tych przesłanek można wyprowadzić wniosek, że z konieczności, wcześniej czy później, transhumanistyczne marzenia zaczną się spełniać.

Wszelako to logiczne rozumowanie jest zasadne jedynie pod warunkiem, że nadal, nieprzerwanie, trwać będzie cywilizacja Zachodu - jedyna w dziejach ludzkości cywilizacja scjentystyczna i personalistyczna zarazem. Jasno i wyraźnie widoczny podwójny kryzys tej cywilizacji - kryzys wartości i kryzys demograficzny - rodzi zwątpienie, czy powyższy warunek będzie spełniony. Być może zbliżamy się nie do świata postczłowieka, lecz do końca świata człowieka cywilizacji zachodniej ${ }^{52}$.

\footnotetext{
${ }^{52}$ Być może w procesy rozwojowe wiedzy i technologii wpisana jest konieczność załamania się cywilizacji rozpoczynającej zmianę natury świata i człowieka. Na temat hipotetycznego punktu krytycznego w dziejach naszej cywilizacji zob. Jerzy Kopania, „Przyczyna sprawcza kryzysu cywilizacji Zachodu”, w: Bezpieczeństwo personalne a bezpieczeństwo strukturalne, t. IV: Bezpieczeństwo w antroposferze i infosferze, red. Teresa Grabińska, Zbigniew Kuźniar (Wrocław: Wydawnictwo Wyższej Szkoły Oficerskiej Wojsk Lądowych im. gen. T. Kościuszki, 2016), 21-38. Omówienie zagadnienia w szerszym kontekście zob. Jerzy Kopania, Maria Nowacka, „Od unieśmiertelniania człowieka do śmierci cywilizacji”, w: Ulepszanie człowieka. Perspektywa filozoficzna, red. Grzegorz Hołub, Piotr Duchliński (Kraków: Wydawnictwo Naukowe Akademii Ignatianum, 2018), 31-70.
} 


\section{Bibliografia}

Alquié Ferdinand. 1989. Kartezjusz, przeł. Stanisław Cichowicz. Warszawa: Pax. Bacon Francis. 1955. Novum Organum, przeł. Jan Wikarjak. Warszawa: PWN.

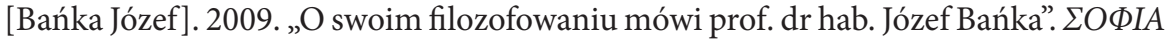
9: 299-322.

Besnier Jean-Michel. 2013. „D’un désir mortifère d'immortalité. À propos du transhumanisme". Cités 55: 13-23.

Bostrom Nick. 2005. „A History of Transhumanist Thought”. Journal of Evolution and Technology 1 (14): 1-25.

Bostrom Nick. „Wartości humanistyczne”, przeł. Elżbieta Binswanger-Stefańska, Sławomir Szostak. Dostęp 27.07.2018. www.racjonalista.pl/kk.php/s,6014.

Bostrom Nick. The Transhumanist FAQ. A General Introduction. Version 2.1 (2003). Dostęp 27.07.2018. https://nickbostrom.com/views/transhumanist.pdf.

Bostrom Nick. „Why I Want to be a Posthuman When I Grow Up”. W: Medical Enhancement and Posthumanity, red. Bert Gordijn, Ruth Chadwick. Dordrecht: Springer, 2008. Dostęp 2707.2018. https://nickbostrom.com/posthuman.pdf.

Boutroux Émile. 1896. „Du rapport de la morale a la science dans la philosophie de Descartes”. Revue de Métaphysique et de Morale” 4 (4): 502-511.

Bradford Katarina. „A Brief on the Transhumanist Movement”. Dostęp 27.07.2018. https://www.str.org/articles/a-brief-on-the-transhumancja-movement\#.WwGbJyAuCUk.

Condorcet Antoine Nicolas. 1957. Szkic obrazu postępu ducha ludzkiego poprzez dzieje, przeł. B. Suchodolski. Warszawa: PWN.

Descartes René. 1958. Medytacje o pierwszej filozofii, przeł. Maria i Kazimierz Ajdukiewiczowie. Warszawa: PWN.

Descartes René. 1958. Namiętności duszy, przeł. Ludwik Chmaj. Warszawa: PWN.

Descartes René. 1970. Rozprawa o metodzie, przeł. Wanda Wojciechowska. Warszawa: PWN.

Descartes René. 1960. Zasady filozofii, przeł. Izydora Dąmbska. Warszawa: PWN.

Drozdek Adam. 2015. „On Cyberimmortality”. Analiza i Egzystencja 31: 5-19.

Harris John. 2007. Enhancing Evolution. The Ethical Case for Making Better People. Princeton-Oxford: Princeton University Press.

Hughes James. 2010. „Contradictions from the Enlightenment Roots of Transhumanism. Journal of Medicine and Philosophy" 6 (35): 622-640.

Hutchins Barnaby R. 2016. „Descartes and the Dissolution of Life”. The Southern Journal of Philosophy 2 (54): 155-173. 
Hutchins Barnaby R. 2016. „Does Descartes Have a Principle of Life? Hierarchy and Interdependence in Descartes's Physiology". Perspectives on Science 6 (24): 744-769.

Huxley Julian. 2015. „Transhumanizm”, przeł. Marta Soniewicka. Ethics in Progress $1(6): 17-22$.

Kopania Jerzy. 2002. Etyczny wymiar cielesności. Kraków: Aureus.

Kopania Jerzy. 2009. „Ekologia kartezjańska - wprowadzenie do problemu”. W: Jerzy Kopania, Szkice kartezjańskie. 181-198. Kraków: Aureus.

Kopania Jerzy. 2016. „Przyczyna sprawcza kryzysu cywilizacji Zachodu”. W: Bezpieczeństwo personalne a bezpieczeństwo strukturalne, t. IV: Bezpieczeństwo $w$ antroposferze $i$ infosferze, red. Teresa Grabińska, Zbigniew Kuźniar, 21-38. Wrocław: Wydawnictwo Wyższej Szkoły Oficerskiej Wojsk Lądowych im. gen. T. Kościuszki.

Kopania Jerzy, Maria Nowacka. 2018. „Od unieśmiertelniania człowieka do śmierci cywilizacji”. W: Ulepszanie człowieka. Perspektywa filozoficzna, red. Grzegorz Hołub, Piotr Duchliński, 31-70. Kraków: Wydawnictwo Naukowe Akademii Ignatianum.

Kurzweil Ray. 2013. Nadchodzi Osobliwość. Kiedy człowiek przekroczy granice biologii, przeł. E. Chodkowska i A. Nowosielska. Warszawa: Kurhaus.

Lem Stanisław. 2010. Moloch. Warszawa: Agora.

Lem Stanisław 2010. Summa technologiae. Warszawa: Agora.

Mackenzie Ann Wilbur. 1975. „A Word about Descartes’ Mechanistic Conception of Life". Journal of the History of Biology 1 (8): 1-13.

Metzinger Thomas. 2009. The Ego Tunnel. The Science of the Mind and the Myth of the Self. New York: Basic Books.

More Max. „H+: True Transhumanism”. Dostęp 27.07.2018. http://www.metanexus. net/essay/h-true-transhumanism.

More Max. „List do Matki Natury”, przeł. M. Sieńko. Dostęp 27.07.2018. http://www. racjonalista.pl/kk.php/s,4003/q,List.do.Matki.Natury.

More Max. „Transhumanism: Toward a Futurist Philosophy”. Dostęp 27.07.2018. http://web.archive.org/web/20130806172107/http://www.maxmore.com:80/ transhum.htm.

Pascal Blaise. 1977. Myśli, przeł. Tadeusz Żeleński (Boy). Warszawa: Pax.

Popper Karl R. 1999. „Utopia a przemoc”. W: Karl R. Popper, Droga do wiedzy. Domysty i refutacje, przel. Stefan Amsterdamski. Warszawa: Wydawnictwo Naukowe PWN.

Rorty Amélie Oksenberg. 1970. „Descartes on thinking with body”. W: The Cambridge Companion to Descartes, red. John Cottingham, 371-392. Cambridge: Cambridge University Press. 
Ryle Gilbert. 1970. Czym jest umyst, przel. Witold Marciszewski. Warszawa: PWN. Savulescu Julian, Ingmar Persson. 2012. „Moral Enhancement, Freedom, and the God Machine". The Monist 3 (95): 399-421.

Vaccari Andrés. 2012 „Dissolving Nature. How Descartes Made Us Posthuman”. Techné. Reseach in Philosophy and Technology 2 (16): 138-186.

\begin{abstract}
René Descartes as a Precursor of the Ideology of Transhumanism

René Descartes's philosophical thought contributed to the dynamic development of the natural sciences, particularly medicine. However, at the same time, it aroused great expectations concerning more and more effective exploitation of natural goods, better protection against all the threats which the natural world may potentially cause to man, but, first of all, it brought expectations of a better, healthier, and longer life. Descartes had such expectations himself; he believed that the development of knowledge would lead to the improvement of the natural world, the human body and psyche, as well as human morality. In fact, it is a dream about improving and perfecting all things which exist in the area of human experience, i.e. the entire reality - both material and spiritual. Modern transhumanists have similar expectations. Even though they have not adopted them directly from the father of modern rationalism, a comparison of Cartesian belief with transhumanist belief is instructive as it facilitates the understanding of the direction in which our civilization is heading.
\end{abstract}

Key words: René Descartes; transhumanism; knowledge.

\title{
Streszczenie
}

\section{René Descartes jako prekursor ideologii transhumanizmu}

Myśl filozoficzna René Descartes’a przyczyniła się do dynamicznego rozwoju nauk przyrodniczych, w szczególności medycyny, zarazem jednak rozbudziła ogromne nadzieje na coraz skuteczniejsze korzystanie z dóbr przyrody, coraz lepsze zabezpieczenie przed tym wszystkim, co z jej strony człowiekowi zagraża, przede wszystkim zaś na coraz lepsze, zdrowsze i dłuższe życie. Sam Descartes też takie nadzieje żywił i wierzył, iż dzięki rozwojowi wiedzy można będzie 
ulepszać i udoskonalać przyrodę, cielesność człowieka, psychika człowieka i ludzką moralność. Faktycznie jest to marzenie o ulepszającym i udoskonalającym zmienianiu wszystkiego, co istnieje w przestrzeni ludzkiego doświadczenia, czyli całej rzeczywistości - zarówno materialnej, jak i duchowej. Tą samą wiarą napełnieni są współcześni transhumaniści, a choć nie przejęli jej bezpośrednio od ojca nowożytnego racjonalizmu, to porównanie wiary kartezjańskiej z wiarą transhumanistyczną jest wymowne i pozwala lepiej zrozumieć, w jakim kierunku zmierza nasza cywilizacja.

Słowa kluczowe: René Descartes; transhumanizm; wiedza. 